
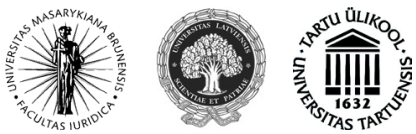

ISSN 1392-6195 (print) ISSN 2029-2058 (online) JURISPRUDENCIJA JURISPRUDENCE 2014, 21(2), p. 599-614.

\title{
FIZINIO SKAUSMO SUKĖLIMO NUSTATYMO IR BK 140 STRAIPSNYJE NUMATYTO NUSIKALTIMO PRIPAŽINIMO MAŽAREIKŠMIU PROBLEMINIAI ASPEKTAI
}

\author{
Kristina Grinevičiūtè \\ Mykolo Romerio universiteto Teisès fakulteto \\ Baudžiamosios teisès ir proceso institutas \\ Ateities g. 20, LT-08303 Vilnius, Lietuva
}

Tel.: (+370 5) 2714584

Elektroninis paštas: kristina.grineviciute@registrucentras.lt

Pateikta 2013 m. gegužès 22 d., parengta spausdinti 2014 m. gegužès 21 d.

doi:10.13165/JUR-14-21-2-13

\section{Ivadas}

Lietuvos Respublikos baudžiamojo kodekso ${ }^{1}$ (toliau - BK) 140 straipsnyje įtvirtinta atsakomybė už mušimą ar kitokị smurtavimą, kurie sukèlè žmogui fizinị skausmą arba nežymiai ji sužalojo ar trumpam susargdino. Šiame straipsnyje nenumatyta jokia riba, nuo kurios fizinis smurtas nelaikomas nusikaltimu, nes esą turi būti baudžiama vien tik už fizinio skausmo sukèlimą. Šios problematikos esmę nusako tai, kad net menkiausias fizinès jègos panaudojimas prieš kitą asmeni pažeidžia asmens kūno neliečiamybę. Žmogaus teisè ị kūno neliečiamybę šiais laikais

1 Lietuvos Respublikos baudžiamojo kodekso patvirtinimo ir įsigaliojimo ịstatymas. Valstybès žinios. 2000, Nr. 89-2741.

Jurisprudencija/Jurisprudence

(C) Mykolo Romerio universitetas, 2014

(C) Mykolas Romeris University, 2014
ISSN 1392-6195 (print), ISSN 2029-2058 (online) http://www.mruni.eu/lt/mokslo_darbai/jurisprudencija/ http://www.mruni.eu/en/mokslo_darbai/jurisprudencija/ 
Vakarų teisès tradicijoje yra viena pamatinių teisių, bet ar tai reiškia, kad bet kokia prievarta ar fizinès jègos panaudojimas, nukreiptas ị kito asmens kūną, visada turi užtraukti baudžiamąją atsakomybę. Atsakymas ị ši klausimą tiesiogiai susijęs su fizinio skausmo nustatymo baudžiamojoje teiseje problematika, todèl šiame straipsnyje analizuojama fizinio skausmo sukèlimo baudžiamojo teisinio vertinimo problema. Šio straipsnio tikslas - sisteminiu, loginiu, teismų praktikos analizės ir kitais tyrimo metodais ịvertinti fizinio skausmo požymio nustatymo problemas, išskirti jo ịrodinèjimo baudžiamosiose bylose kriterijus. Kartu bandoma atsakyti, ar fizinis skausmas ir nežymus sveikatos sutrikdymas gali būti pripažinti mažareikšmèmis veikomis.

Reikia pripažinti, kad nors šis nusikaltimas BK numatytas seniai, o jo taikymo praktika yra labai aktuali socialiniu požiūriu, baudžiamosios teisès teorijoje jam skiriama santykinai nedaug dèmesio. Galima paminèti tik kelis mokslinius darbus (R. Aliukonienès ${ }^{2}$, I. Vitkutès-Zvezdinienės ${ }^{3}$ ), kuriuose analizuojami sveikatos sutrikdymo ar nusikalstamos veikos mažareikšmiškumo klausimai.

\section{BK 140 straipsnyje ịtvirtinto fizinio skaumo sukèlimo požymio turinys ir jo nustatymo probleminiai aspektai}

BK 140 straipsnio tikslas - apsaugoti žmogų nuo fizinio skausmo sukèlimo. Objektyviai veika pasireiškia mušimu ar kitais smurtiniais veiksmais, t. y. fiziniu smurtu. Fizinis smurtas - pavojingas, neteisètas, tyčinis poveikis kito žmogaus organizmui, kuris atliekamas prieš asmens valią arba be jo sutikimo bei galintis pasireikšti žmogaus audinių ar organų anatominio vientisumo arba funkcijų pažeidimais, skausmo sukèlimu, judejjimo laisvès apribojimu ${ }^{4}$. Fizinio smurto padariniai gali būti ịvairūs: gyvybės atemimas, sveikatos sutrikdymas, skausmo ar kitokių fizinių kančiu sukèlimas, laisvès atėmimas ar bejègiškumo būklès sukèlimas. BK 140 straipsnis kriminalizuoja vieną iš lengvesnių fizinio smurto padarinių - fizinio skausmo sukèlimą. Reikètų paminèti, kad fizinis smurtas ne visada sukelia fizinị skausmą, o ir ne kiekvienas sukeltas fizinis skausmas yra pavojingas, neteisètas ir žalingas. Taikant baudžiamąją atsakomybę už fizinio skausmo sukẻlimą reikia protingai nustatyti šios veikos baudžiamumo ribas. Asmens padarytos veikos pripažinimas nusikaltimu neturi būti daromas vien formaliai, nevertinant, ar tokios veikos neteisètumas yra kriminalinio pobūdžio ir ar jos pavojingumas yra pakankamas ją laikyti nusikaltimu. Nepakanka formalaus konstatavimo, kad yra sukeltas fizinis skausmas. Baudžiamoji

2 Žr., pvz., Aliukonienè, R. Nusikaltimų žmogaus sveikatai samprata. Nepriklausomos Lietuvos teisè: praeitis, dabartis ir ateitis. Vilnius: Vilniaus universitetas, 2012, p. 130-143.

3 Žr., pvz., Vitkutė-Zvezdinienè, I. Nusikaltimo mažareikšmiškumo atribojimo nuo baudžiamojo nusižengimo problemos. Jurisprudencija. 2007, 8(98): 35-40.

$4 \quad$ Žr., pvz., Sharapov, R. D. Fizicheskoe nasilie v ugolovnom prave [Physical abuse in criminal law]. Sankt-Peterburg: Juridicheskij centr Press, 2001, p. 290. 
atsakomybė gali būti taikoma tik tuo atveju, kai asmens elgesio neteisètumas siekia būtiną baudžiamosios atsakomybès taikymui pavojingumo laipsnį. Sukelto skausmo intensyvumas ir stiprumas, taip pat skausmo keliamas pavojus konkretaus žmogaus sveikatai ar gyvybei yra baudžiamosios atsakomybės taikymo kriterijai.

Teismai vertindami atitinkamą elgesị kaip fizinị smurtą atkreipia dèmesị i tai, kad baudžiamoji teisè yra kraštutinè priemonè, taikoma tik už žalingą elgesị. Štai vienoje byloje šeimynos globotinè apkaltino darbuotoją fizinio skausmo sukèlimu: S. P. suèmé nukentejjusiajai už rankos, kurioje buvo telefonas, ir kita ranka atlenkęs jos rankos pirštus paèmè telefoną. Apeliacinès instancijos teismas išteisino S. P. nepadarius nusikaltimo, numatyto BK 140 straipsnio 2 dalyje (BK redakcija, galiojusi iki 2013 m. liepos 13 d.). Teismas nenustatè, kad bütų naudotas fizinis smurtas (mažameté nebuvo mušama, kankinama ar kitaip priě̌ ja smurtaujama). S. P. atlikdamas jam pavestas funkcijas, siekdamas užtikrinti, kad A. D. laikytųsi nustatytos tvarkos ir nakties metu netriukšmautu tyčia garsiai kalbèdama telefonu, po to, kai ši nereagavo i daugkartinius perspejimus, iš jos ranku paemè mobiluji telefona. Teismas pažyméjo, kad baudžiamoji atsakomybè už fizinio skausmo sukèlima galima tik nustačius, jog kaltininkas neabejotinai atliko istatymo dispozicijoje nurodytus veiksmus, kurie istatymy leidejo pripažistami kaip neabejotinai sukeliantys fizinị skausmą. S. P. jejga panaudojo išimtinai tik tam, kad nutrauktu aiškiai neteisètus veiksmus, o ne tam, kad jai sukeltu fizini skausmą

Kiekvienu konkrečiu atveju būtina analizuoti, ar pakankamas padarytų veiksmų pavojingumas, ar padaryta žala, ar yra pakankamai tai įrodančių duomenų. Kasacineje praktikoje ne kartą pabrèžta, kad baudžiamoji teisè nėra formali, ji nustato atsakomybę tik už pavojingas veikas, o ne formalius pažeidimus. Pavyzdžiui, susistumdymas prie autobuso durų, stiprus rankos paspaudimas, siekiant sukelti fizinị skausmą, lengvas pliaukštelejimas ị sẻdynę, ǰžeidžiantis kabinejjimasis, pasireiškiantis tampymu už rankų, ir kt. Išvardinti pavyzdžiai nẻra tinkamas elgesys (o jam neabejotinai reikalinga tam tikra fizinè jèga), bet panaudota fizinè jèga yra minimali. Tokie veiksmai nesiekia nusikaltimams būdingo pavojingumo laipsnio bei neatitinka BK 140 straipsnyje aprašytos veikos prasmès ir logikos. Nustatytos bylos aplinkybės turi patvirtinti pačios veikos nusikalstamą pobūdị.

E. K. žaidybiniai veiksmai su anūku, suspaudžiant pastarajam nosi, dèl ko atsirado kraujosruva, negali büti traktuojami kaip nusikaltimas, numatytas BK 140 straipsnio 2 dalyje (BK redakcija, galiojusi iki 2013 m. liepos 13 d.), kadangi surinktoje medžiagoje nèra jokiu duomenu apie E. K. elgesĭ, prieštaraujantị mažamečio anūko interesams. Vaikiškǔ žaidimų metu atsiradę nežymūs sveikatos sutrikdymai ar patirtas mažareikšmis fizinis skausmas, sąlygotas neatsargių ar objektyvių (ịvairūs sutrenki-

5 Panevėžio apygardos teismo Baudžiamųjų bylų skyriaus teisèjų kolegijos $2012 \mathrm{~m}$. balandžio $30 \mathrm{~d}$. nuosprendis byloje (bylos Nr. 1A-295-350/2012). 
mai, nubrozdinimai, ̨̣brěžimai ir pan.) priežasčių, nesudaro BK 140 straipsnio 2 dalyje numatytos veikos sudeties ${ }^{6}$.

Baudžiamasis įstatymas saugo teisines vertybes nuo esminės žalos. Teisinè vertybė saugoma baudžiamosiomis teisinemis priemonėmis, kai jai gresia apčiuopiama žala, pasireiškianti pavojingų padarinių atsiradimu. Kèsinimasis ị žmogų apima ne tik smurtinį žmogaus fizinès būklès pasikeitimą, bet ir nemalonių pojūčių, fizinio skausmo, kančios sukèlimą. Veikos pavojingumas priklauso nuo fizinio smurtinio poveikio aukai, tai yra nuo to, kaip auka jaučiasi poveikio metu ir po jo. BK 140 straipsnyje ittvirtinti du padariniai: nežymus sveikatos sutrikdymas ir fizinis skausmas, yra labai skirtingi. Iš teismų praktikos matyti, kad BK 140 straipsnyje numatyti padariniai - nežymus sveikatos sutrikdymas ir fizinis skausmas - nustatomi remiantis Sveikatos sutrikdymo masto nustatymo taisyklemis (toliau - Taisyklès) ${ }^{7}$. Šios taisyklès iš esmès apibūdina BK 140 straipsnyje nustatytus sveikatos sutrikdymo požymius, nes tai numatyta BK 141 straipsnyje pateikiant sąvokų išaiškinimą. Taisyklių 1 dalies 2 punkte įtvirtinta, kad sveikatos sutrikdymo faktą ir mastą nustato teismo medicinos ekspertai. Šiuo aspektu sunkumų kyla tada, kai nustatomas fizinis skausmo sukèlimas. Baudžiamosios teisès teorijoje vienareikšmiškai pripažistama, kad fizinio skausmo sukèlimas apima tik tuos atvejus, kai smurto veiksmai nesukelia kūno sužalojimo, susargdinimo bei kitų padarinių, numatytų kituose BK straipsniuose, ir veika nebuvo padaryta siekiant tokių padarinių. Fizinio skausmo sukèlimas nepalieka ant nukentẻjusiojo kūno pẻdsakų, kuriuos galètų užfiksuoti medikai ${ }^{8}$. Nežymaus sveikatos sutrikdymo atveju realią žalą sveikatai medicina gali gana tiksliai nustatyti, tačiau fizinio skausmo sukèlimo atveju, kai nepažeidžiamas audinių ar organų anatominis vientisumas arba jų fiziologinès funkcijos, fizinio skausmo sukèlimo fakto nustatymas tampa problema. Pagal egzistuojančią teismų praktiką, kvalifikuojant kaltininko veiką kaip fizinio skausmo sukèlimą, neteikiama didelès reikšmės ekspertų išvadoms.

Teisejju kolegija pažymi, kad konstatuoti fizini skausma nèra bütinos specialios žinios. Fizinis skausmas - tai nemalonus jausmas, ipprastinès sveikos būsenos pokytis, sukeliantis neigiama organizmo reakciją, nebüdingas pojūtis, kančia, priešingybè malonumui. Nustatant fizinị skausma nèra būtinos pasekmès - sužalojimas, susargdinimas. Žmogaus galva yra vienas iš svarbiausių kūno organų, galvos odoje esančios plauku šaknys jautriai reaguoja ir nerviniais odos receptoriais perduoda visam organizmui neigiama reakcija i plauku tempimo, plauku šaknų rovimo iš odos poveikius. Plauku tempimas kaip dirgiklis neišvengiamai sukelia nevalinga organizmo reakcija refleksa,

6 Kauno apygardos teismo Baudžiamųjų bylų skyriaus teisèjo $2012 \mathrm{~m}$. gruodžio $21 \mathrm{~d}$. nutartis byloje (bylos Nr. 1S-2084-317/2012).

7 Sveikatos sutrikdymo masto nustatymo taisyklès. Valstybės žinios. 2003, Nr. 52-2357.

8 Žr. pvz., Abramavičius, A., et al. Baudžiamoji teisè. Specialioji dalis. 1 knyga. Vilnius: Eugrimas. 2001, p. 199; Abramavičius, A., et al. Lietuvos Respublikos baudžiamojo kodekso komentaras. Specialioji dalis (99-212 straipsniai). Vilnius: valstybės įmoné Registrų centras. 2009, p. 145. 
sukelia fizinị skausmą. Atsižvelgiant ị tai, jog T. S. tyčia sugriebé už plauku S. V., laikydama už plaukų tempé, tai akivaizdu, jog nukentejjusiajai sukèlé fizinị skausmą ${ }^{9}$.

Manytina, kad tokiai teismų praktikai ittaką padarė minètos Taisyklès, kuriose fizinio skausmo nustatymui skiriama labai mažai dèmesio, t. y. jose nèra jokių medicininių kriterijų tokiai žalai nustatyti. Taisyklių 8 punkte įtvirtinta, kad išvadą dèl fizinio skausmo sukèlimo teismo medicinos ekspertai daro remdamiesi bylos medžiagos duomenimis, patvirtinančiais buvusị mušimo ar kitokio smurtavimo faktą ${ }^{10}$. Iš esmès tokị faktą gali nustatyti ir pats teismas, nes fakto nustatymas yra teismo kompetencija. Tokio pobūdžio bylose vyrauja praktika, kad išvada paprastai yra pagrindine ịrodinejjimo priemonè. Tačiau eksperto išvada - tai tik viena iš priemonių teismui padaryti teisinę išvadą. Fizinio skausmo sukèlimo nustatymo atveju specialios medicininès žinios per daug sureikšminamos, nes, kaip minèta, taisyklèse nèra ịtvirtinta jokių medicininių kriterijų fizinio skausmo sukèlimui konstatuoti, todèl šị faktą gali nustatyti ir teismas.

Teismams dažnai kyla sunkumų nustatant, ar smurtiniai veiksmai sukèlè fizinị skausmą ar ne, kadangi teismo ekspertų išvadose būna pateikta tik prielaida apie skausmo kilimo galimybę. Fizinis skausmas nèra vienareikšmis ir pavojingumo prasme gali būti labai skirtingų formų, todèl negali būti nustatinejjamas ir pripažįstamas automatiškai. Fizinis skausmas pasireiškia nemaloniais pojūčiais, o tai - nukentèjusiojo subjektyvus suvokimas. Fizinio skausmo kilimas yra nukentejjusiojo reakcija i jam daromą fizinị smurtinị poveikį. Lietuvos teismų praktikoje, vertinant fizinio skausmo kilimą, nukentejjusiojo suvokimui kartais suteikiama lemiama reikšmė:

P. K. buvo kaltinamas pagal BK 140 straipsnio 2 dali (BK redakcija, galiojusi iki 2013 m. liepos 13 d.) už tai, kad pakèlęs mažameti sūnų už rūbų metè ant grindų, taip sukeldamas fizinị skausmą. Teismas ịvertinęs aštuoneriu metu vaiko parodymus, kad jis verke dèl tokio tèvo elgesio ir kad jam nieko neskaudejo, bei vaiko atstovés skirtingus parodymus, dèl ko vaikas verkè, padarè prielaidą, jog mažametis galejo išsigąsti brutalaus girto tèvo elgesio ir verkti iš išgąsčio. Teismas konstatavo, kad nesurinkta neginčijamų įrodymų, jog P. K. smurtaudamas sukèle fizinį skausmą mažamečiui sūnui, todèl kaltinamasis išteisintas ${ }^{11}$. Šiame nuosprendyje diskutuotinas nukentejuusiojo reakcijos ị jam daromą fizinị poveikị sureikšminimas. Juk vertinama turi būti kaltininko veika, o ne nukentejjusiojo reakcija. Pats nukentejjusysis gali suklysti, neadekvačiai ịvertinti situaciją. Šiuo atveju nukentejjusysis - aštuonerių metų vaikas. Psichologijoje ne kartą pabrèžta $^{12}$, kad labai dažnai skausmą lydi baimė ir ịtampa, ir šios trys emocijos yra

9 Kauno apygardos teismo Baudžiamųjų bylų skyriaus teisèjų kolegijos $2012 \mathrm{~m}$. birželio $11 \mathrm{~d}$. nutartis byloje (bylos Nr. 1A-462-508/2012).

10 Sveikatos sutrikdymo masto nustatymo taisyklès, supra note 7.

11 Šilalès rajono apylinkès teismo $2012 \mathrm{~m}$. kovo 23 d. nuosprendis byloje (bylos Nr. 1-55439/2012).

12 Žr., pvz., Lesinskienè, S.; Karalienè, V. Emocinès raidos įtaka tolimesniam vaiko asmenybès vystymuisi. Vilnius: Specialiosios pedagogikos ir psichologijos centras, 2008, p. 43. 
glaudžiai tarpusavyje susijusios. Nukentejusiojo suvokimas gali būti klaidingas ir $\mathrm{ji}$ irgi reikia vertinti (ar jis atitiko situaciją). Be abejo, tai, kaip nukentejusysis suprato prieš jị nukreiptus veiksmus, yra labai svarbu, tačiau pagrindiniu kriterijumi šios aplinkybès laikyti nereikètų. Teismas šiuo atveju neatsižvelgè ị tas aplinkybes, kad tuo pačiu metu kaltininkas smurtavo sugyventinès (vaiko motinos) atžvilgiu, kad nukritęs vaikas verkè, kad nutraukè veiksmus tik pagrasinus iškviesti policiją, kad jis teisiamas už fizinio smurto panaudojimą savo šeimos narių atžvilgiu trečią kartą ir pan.

Yra ir kitas teisinėje literatūroje išsakytas požiūris ị fizinio skausmo nustatymą, siejant ji ne su subjektyviu, o su objektyviu kriterijumi. Štai Rusijos baudžiamosios teisès mokslininkai siūlo fizinio skausmo nustatymo kriterijumi laikyti adekvataus (vidutinio) žmogaus kriterijų ${ }^{13}$. Remiantis šiuo kriterijumi, teismas kiekvieną kartą turi vertinti, ar veiksmų pobūdis galèjo realiai sukelti apčiuopiamą fizinị skausmą. Fizinis poveikis turi būti tokio pobūdžio ir intensyvumo, kad vidutinis žmogus pajustų fizini skausmą. Atrodytų, kad šis objektyvus adekvataus žmogaus kriterijus neišsprendžia fizinio skausmo nustatymo problemos. Skausmas yra pojūtis, o visi žmonès individualiai ir subjektyviai reaguoja ị patiriamą skausmą. Skausmo jautrumo slenkstis gali būti labai nevienodas, skausmas gali labai skirtis savo pobūdžiu ir intensyvumu.

Norint nustatyti analizuojamo nusikaltimo sudėties požymio - fizinio skausmo sukèlimas - buvimą, reikia ištirti, kaip kaltinamasis ir nukentejusysis aiškina buvusią situaciją, taip pat ir visas kitas objektyvias ir subjektyvias aplinkybes, t. y. reikia remtis konkretaus nukentejjusiojo suvokimu (subjektyviuoju kriterijumi), fizinio poveikio gebẻjimu paveikti vidutini žmogų (objektyviuoju kriterijumi) ir kitomis aplinkybèmis. Šio straipsnio autorès nuomone, tokiomis aplinkybemis laikytinos:

1) įvykio aplinkybės: ar taip ịprasta elgtis, ar toks elgesys yra pateisinamas, kaip jis gali būti paaiškintas atsižvelgiant ị situacijos specifiką, ar naudotas smurtas kitų asmenų atžvilgiu ir pan.;

2) nusikaltimo padarymo ịrankius, būdą, vietą: ar kaltininkas turèjo kokių nors daiktų, skirtų kūnui sužaloti, ar fizinis poveikis buvo nukreiptas ị gyvybei svarbius organus;

3) nusikalstamų veiksmų intensyvumą ir jų nutraukimo priežastis;

4) kaltininko ir nukentejusiojo tarpusavio santykius, elgesị ịvkio metu, taip pat prieš nusikaltimą ir po jo padarymo ir kt.;

5) kaip nukentejusysis suvoke kaltininko veiksmus ir kaip jis elgèsi;

6) kaltininko tyčios kryptingumą, ko kaltininkas siekè tokiais veiksmais.

Šios aplinkybès ir leidža daryti išvadą apie fizinio skausmo konkrečioje situacijoje buvimą, o visą veiką pripažinti fizinio skausmo sukèlimu. 


\section{Fizinio skausmo sukèlimo ir nežymaus sveikatos sutrikdymo kaip mažareikšmés veikos vertinimas teismų praktikoje}

Fizinis skausmas atsiranda kaip signalas į žalojantị poveikį audiniams, jis parodo kilusią, nors kartais ir menkavertę, žalą žmogaus sveikatai. Teismams nuolat tenka spręsti, ar fiziniai smurtiniai veiksmai nèra mažareikšmiai.

Teismų praktika dèl klausimo, ar gali būti laikoma veika mažareikšme, kai padaryta ar siekiama padaryti fizinę žalą kito asmens sveikatai, yra nevienareikšmè. Tam ịtaką padare ir Lietuvos Aukščiausiojo Teismo senato $2000 \mathrm{~m}$. gruodžio $21 \mathrm{~d}$. nutarimas Nr. 29 „Dèl teismų praktikos veikas pripažistant mažareikšmėmis“. Šio nutarimo 15 punkto antra dalimi teismai orientuojami ị tai, kad neturètų būti pripažintos mažareikšmėmis veikos, kuriomis buvo padaryta ar siekiama padaryti fizine žala kito asmens sveikatai, tačiau to paties punkto trečioji dalis daro išimtį, kad tam tikrais atvejais, atsižvelgdamas i padarytos veikos tikslus ir motyvus, kaltininko ir nukentejusiojo tarpusavio santykius, nusikaltimo padarymo būdą, intensyvumą bei kitus šio nutarimo 4 punkte išvardytus požymius, teismas veiką, kuria kitam asmeniui padarytas tyčinis lengvas kūno sužalojimas, smūgių sudavimas, gali pripažinti mažareikšme.

Pagrindinè šios diskusijos priežastis yra ta, kad net menkiausias fizinès jègos panaudojimas kito asmens atžvilgiu pažeidžia žmogaus kūno neliečiamybę ir orumą. Asmens neliečiamumas yra pamatinis teisinis principas, kuris reiškia, kad žmogus privalo būti apsaugotas nuo neteisèto fizinio poveikio. Atsižvelgiant ị tai teisinėje literatūroje kartais teigiama, jog fizinès prievartos panaudojimo atveju veika negali būti laikoma mažareikšme ${ }^{14}$. Teisé neatleidžia nusikaltimų ir pažeidimų dẻl to, kad žala yra nedidelè. Žalos dydis yra svarbus tik skiriant bausmę ${ }^{15}$.

Vis dèlto manytina, kad nereikètų griežtai neigti galimybès pripažinti tam tikrus nežymaus sveikatos sutrikdymo ar fizinio skausmo sukèlimo atvejus mažareikšmiais.

Pagal susiklosčiusią teismų praktiką, sprendžiant klausimą dẻl nusikaltimo mažareikšmiškumo, atsižvelgiama tiek ị veikos objektyviuosius (kokios baudžiamojo i̇statymo saugomos vertybės pažeistos ir jų pažeidimo laipsnis, veikos ypatumai, nusikaltimo dalykas ir jo ypatumai, kilę padariniai, nusikaltimo padarymo būdas, laikas vieta), tiek ị subjektyviuosius požymius (apibrèžta ar neapibrèžta tyčia, tyčios kryptingumas, tikslai, motyvai). Ar nusikaltimas laikytinas mažareikšmiu, remdamasis byloje nustatytomis aplinkybėmis kiekvienu konkrečiu atveju sprendžia teismas. Sprendimą byloje būtina priimti atsižvelgiant ị visas reikšmingas bylos aplinkybes. Kokios aplinkybès reikšmingos, o kokios ne, yra vertybinis ir dèl to neabejotinai

14 Žr., pvz., Stewart, H. Parents, Children, and the Law of Assault. The Dalhousie Law Journal. 2009, 32.

15 Žr., pvz., Nemerofsky, J. What is a „Triffle” Anyway? Gonzaga Law Journal. 2001-2002, 37: 315-341. 
ginčytinas klausimas. Autorès nuomone, mažareikšmiškumas - veikos pavojingumo vertinimas, kurị parodo daug aplinkybių. Manytina, kad nustatant nusikaltimo mažareikšmiškumą būtina atsižvelgti ị aplinkybių visumą: kas, kam, kaip ir kodèl panaudojo fizinius smurtinius veiksmus, kokių tikslų siekė ir pan. Esant vienoms aplinkybėms fiziniai smurtiniai veiksmai gali būti pripažinti nepavojingais ir asmuo bus išteisintas, esant kitoms - mažareikšmiais ir asmuo bus atleistas nuo baudžiamosios atsakomybès, o trečioms - iš tiesų pavojinga veika, kai asmeniui bus skiriama bausmè. Fizinių smurtinių veiksmų pobūdis ir intensyvumas, sukeltų padarinių stiprumas, tyčios kryptingumas ir kt. aplinkybès yra itin svarbūs kriterijai. Smulkūs fiziniai kontaktai, neintensyvus fizinis smurtas ir pan., kurie nepadaro reikšmingos žalos asmeninėms vertybėms, turètų neužtraukti baudžiamosios atsakomybès.

Teismų praktikoje mažareikšmiu nusikaltimu pripažistama veika: 1) kuri tik formaliai atitinka nusikaltimo sudèties požymius, bet iš esmès nedaro žalos įstatymo saugomoms vertybėms ar nesukelia pavojaus tokiai žalai atsirasti, arba 2) kuri nesiekia tokio pavojingumo laipsnio, dèl kurio būtų tikslinga kaltininką už padarytą nusikaltimą traukti baudžiamojon atsakomybèn.

Pastarasis argumentas teismų sprendimuose yra itin dažnas. Teismai argumentuodami, kodèl nusikaltimas yra mažareikšmis, nurodo protingumo, sąžiningumo, teisingumo principus bei tai, kad baudžiamoji teisė yra ultima ratio. Pavyzdžiui, vienoje byloje buvo ịvertintas drausminès atsakomybès veiksmingumas už mokytojos pareigų pažeidimą. Teismas konstatavo, kad mokytoja V. S. pasirinko neadekvačias ir kartu neteisètas priemones - nukentèjusiajam V. A. priešinantis - jị iš klasès pašalino naudodama fizine jèga, kaip to pasekmę nukentèjusysis patyré fizinị skausma bei nežymu sveikatos sutrikdymą. Nuteistosios veiksmai nepasireiške smügiu sudavimu, nukentejjusiajam buvo tik suimta už ausies bei kaklo, veiksmai nebuvo intensyvūs ar ilgalaikiai. Baudžiamoji teise kaip teisinio reguliavimo priemone yra laikoma ultima ratio, tai yra sankciju ịtvirtinimo baudžiamaisiais ìstatymais turi būti imamasi tik tada, kai neimanoma kitomis socialinèmis, teisinèmis priemonèmis ginti teisiniu gèriu. [...] Už minètq veika nuteistoji jau yra nubausta drausmine tvarka - jai pareikštas papeikimas, todèl teisèju kolegija mano, jog tai buvo pakankama nubaudimo prie$m_{0 n} \dot{1}^{16}$. Kitoje byloje, teismas ją nutraukdamas dèl nusikaltimo mažareikšmiškumo, pasisakè, kad baudžiamoji atsakomybe nèra vienintele poveikio priemoné teisés pažeidejai teisinés atsakomybès formu sistemoje. CK 3.180 str. 1 d. įtvirtina tai, kad teismas gali priimti sprendima dèl laikino ar neterminuoto tèvu valdžios apribojimo ${ }^{17}$. Atliekant vertinimą teisingumo ir proporcingumo, ultima ratio principų kontekste svarbu nepamiršti ne tik to subjekto, kurio atžvilgiu taikoma tam tikra priemone (t. y. kaltininko), bet ir nukentejusiojo interesų. Pirmiausia būtina analizuoti, ar pa-

16 Panevėžio apygardos teismo Baudžiamųjų bylų skyriaus teisèjų kolegijos $2012 \mathrm{~m}$. gegužès $18 \mathrm{~d}$. nuosprendis baudžiamojoje byloje (bylos Nr. 1A-19-511/2012).

17 Klaipèdos apygardos teismo Baudžiamụjų bylų skyriaus teisejų kolegijos $2007 \mathrm{~m}$. lapkričio $15 \mathrm{~d}$. nutartis baudžiamojoje byloje (bylos Nr. 1S-108-361/2007). 
kankamas veikų pavojingumas, įvertinti ar kitos teisės šakos tikrai veiksmingos atkuriant pažeistas teises.

Teismų praktikoje ne kartą pabrèžta, kad žmogaus sveikata yra viena svarbiausių, nesunkiai pažeidžiamų ir ne visada atkuriamų vertybių, kuriai taikoma išskirtinė teisiné apsauga ${ }^{18}$. Atitinkamai pabrěžiama, kad nusikalstama veika padarytos žalos pobūdis ir dydis yra pats svarbiausias ir lemiantis kriterijus vertinant nusikaltimą kaip mažareikšmį. Teismų praktikoje dažnas atvejis, kai mažareikšme veika pripažìstamas nežymus sveikatos sutrikdymas ar fizinio skausmo sukèlimas, padarytas per abipusị konfliktą, virtusị muštynėmis. Tokiais atvejais teismai neretai ryžtingai kaltininką atleidžia nuo baudžiamosios atsakomybès dẻl nusikaltimo mažareikšmiškumo:

A. G. suduodama viena karta nukentèjusiajai O. P. ị veidą, sukèle jai fizinị skausmą. Byloje nustatyta, kad A. G. smurtą prieš nukentèjusiają O. P. panaudojo siekdama sutramdyti ja, nes ji prieš I. S. smurtavo (spyrè i nugara, trenkè ranka) ir vadino ja necenzūriniais žodžiais, tai yra kèlè konfliktą. A. G. sudavè vieną smūgi nukentejjusiajai, smūgis nebuvo stiprus, kas rodo jos neapibrèžta tyčią. Sukelti didelị fizinị skausmą ar padaryti tam tikrus sužalojimus A. G. nesieke. Smurtas buvo minimalus ir momentinis. A. G. padarytos veikos pavojingumas nèra didelis ir nesiekia tokio laipsnio, dèl kurio būtų tikslinga ja už padaryta nusikaltima traukti baudžiamojon atsakomybèn ir bausti istatymo sankcijoje numatyta bausme. Tokiu būdu A. G. padarytas nusikaltimas laikytinas mažareikšmiu, dèl ko yra pagrindas A. G. atleisti nuo baudžiamosios atsakomybés ${ }^{19}$.

Visiškai logiški ir teisingi teismo motyvai, jog agresoriai privalo pakęsti tam tikrą fizinị poveikį. Vertinant padarytos žalos dydị, žala buvo padaryta, tačiau sutiktina su teismo padaryta išvada, kad ji tikrai nebuvo didelè. Kai konfliktuoja kelios šalys, svarbu atsižvelgti ị šalių fizines galimybes, smūgių pobūdị, panaudotą jẻgą ir jos intensyvumą, elgesio tikslus ir motyvus, konflikto vietą, sąlygas ir kt. aplinkybes. Tokia teismo motyvacija taip pat atitinka baudžiamojo poveikio priemonių ekonomijos, proporcingumo ir teisingumo principus.

Kaip minèta, esminis nusikaltimo mažareikšmiškumo kriterijus yra kilę padariniai, tačiau teismai ne visada tinkamai ịvertina padarytos žalos dydị tokio pobūdžio bylose. Veika mažareikšme pripažintina tik tuo atveju, kai ji iš esmès nepadaro žalos i̊statymo saugomiems teisiniams gériams, t. y. ji turi būti nereikšminga įstatymo saugomoms vertybems.

D. C. kilusio konflikto tarp mažametès dukters K. C. metu, sugriebusi ja už galvos, pastūmé, nuo ko ji nugriuvo ir susitrenkè galvą i dujinę. Po to, dukrai išbègus iš namu ir pargriuvus, sudave tris kartus ranka i nugaros sriti bei du kartus spyrè $i$ kojas, tuo sukeldama K. C. nežymų sveikatos sutrikdymą. Teismas atsižvelgdamas į ìvykio kili-

18 Žr., pvz., Lietuvos Aukščiausiojo Teismo Baudžiamųjų bylų skyriaus teisejų kolegijos $2008 \mathrm{~m}$. kovo 4 d. nutartis baudžiamojoje byloje (bylos Nr. 2K-68/2008).

19 Šiaulių apygardos teismo Baudžiamųjų bylų skyriaus teisejjų kolegijos $2010 \mathrm{~m}$. vasario $18 \mathrm{~d}$. nuosprendis byloje (bylos Nr. 1A-19-282/2010). 
mo priežastis, asmeninius kaltinamosios ir nukentèjusiosios santykius, konstatavo, kad yra pagrindas taikyti BK 37 straipsnį. Nustaté, kad dèl nukentéjusiosios netinkamo elgesio kilo incidentas, kuris paveike D. C. elgesi, lemmusi jos daromos veikos tikslus ir motyvus. K. C. kokie nors rimtesni sužalojimai nebuvo padaryti $i^{20}$.

Tokia motyvacija kelia didelių abejonių, ar tokiu būdu yra pakankamai ginami vaiko interesai. Nusikaltimas sukèle žalingus padarinius - sveikatos sutrikdymą. Nusikaltimas padarytas prieš artimą asmeni - vaiką, kuris nusikalstamos veikos darymo metu buvo mažametis. Vaiko elgesys, nors ir provokuojantis konfliktą, nepateisina tokio brutalaus kaltininko elgesio. Minètos aplinkybės švelnina kaltinamojo atsakomybę bei mažina veikos pavojingumo laipsnị, tačiau nesuteikia pagrindo teigti, kad iš esmès nepadaryta žalos baudžiamojo įstatymo saugomoms vertybėms.

Kitas aktualus diskusinis klausimas, kokią ịtaką daro veikos tikslai ir motyvai nustatant fizinio skausmo sukèlimo ir nežymaus sveikatos sutrikdymo veikos mažareikšmiškumą auklèjant vaikus. Teisineje literatūroje yra keletas požiūrių ${ }^{21}$. Galima būtų pritarti nuomonei, kad veikos tikslas ir motyvas mažina veikos pavojingumą, tačiau tokią išvadą galima daryti išskirtiniais atvejais. Asmuo, naudojantis jègą, turi suvokti, kad ji yra auklèjimo ir pataisymo tikslas; motyvas negali būti pyktis ar susierzinimas; negali būti naudojami ịrankiai ir priemonès; taikyta bausmè turi būti proporcinga nusižengimui ir vaiko amžiui; ir t. t. Pasitaiko atvejų, kai teismai atsižvelgdami ị padarytos veikos tikslą ir motyvą, kaltininko ir nukentejusiojo tarpusavio santykius, per daug formaliai ịvertina padarytą žalą:

Teismas atleisdamas A. B. nuo baudžiamosios atsakomybès konstatavo, kad A. B. yra nukentejusiojo mama, ju tarpusavio santykiai yra labai glaudūs, artimi. Nusikalstama veika padaryta suduodant du ar tris smūgius odiniu diržu į kairę šlaunį, iš ju pagal specialisto išvada - nežymus sveikatos sutrikdymas padarytas galimai vienu kontaktiniu smūgiu. Suduota ne į gyvybiškai pavojinga kūno vietą, veiksmai nebuvo intensyvūs ar ilgalaikiai. Iš surinktos ikiteisminio tyrimo medžiagos matyti, kad A. B. suduodama du ar tris smūgius odiniu diržu ị kairę šlaunị mažamečiui savo sūnui M. B., taip sieke socialiai naudingu tikslu, t. y. ji paauklèti - neimti svetimu pinigu. Nukentejjusysis M. B. apklausiamas ikiteisminio tyrimo metu parode, kad buvo slaptai paèmęs pinigu. A. B. padaryta veika pagal jos objektyviu ir subjektyviu požymiu turini, ju pasireiškima néra pasiekusi tokio pavojingumo laipsnio, jog, vertinant šia veika pagal protingumo, proporcingumo, teisingumo ir kitu bendruju teisés principu nuostatas, taip pat BK 37 straipsnio nuostatu kontekstą, bütu pagristas represiniu baudžiamojo proceso, baudžiamosios teisés priemonių taikymas šiq veiką padariusiai A. B. ${ }^{22}$

20 Šilutès rajono apylinkès teismo $2006 \mathrm{~m}$. gruodžio $12 \mathrm{~d}$. nuosprendis baudžiamojoje byloje (bylos Nr. 1-449-351/2006).

21 Žr., pvz., Grinevičiūtè, K. Fizinès bausmès vaikams: baudžiamasis teisinis vertinimas. Socialiniu mokslu studijos. 2011, 3(2): 721-736.

22 Klaipedos apygardos teismo Baudžiamujų bylų skyriaus teisèjų kolegijos $2007 \mathrm{~m}$. lapkričio $15 \mathrm{~d}$. nutartis baudžiamojoje byloje (bylos Nr. 1S-108-361/2007). 
Tokie smurtiniai veiksmai negali būti laikomi nepavojingais, mažareikšmiais, nepadarę žalos baudžiamojo įstatymo saugomiems teisiniams gèriams. Atsižvelgiant ị fizinị, protinị ir socialinị mažamečio vaiko nesubrendimą, jo nesugebejjimą pasinaudoti savo teisėmis bei apginti savo interesų, baudžiamasis ịstatymas nustato jam ypatingą teisinę apsaugą. Toks elgesys su vaiku yra nusikalstamas ir netoleruotinas. Esminę reikšmę šiuo atveju turi ne nukentejjusiojo veiksmų (net ir neteisètų) pobūdis, jų sukelti padariniai, bet kaltininko veika, šios veikos padarymo būdas (panaudotas diržas) bei sukelti padariniai.

Lietuvos teismuose nagrinėtų baudžiamųjų bylų analizė leidžia spręsti, kad nusikaltimas nepripažįstamas mažareikšmiu, kai: 1) rezultatui pasiekti panaudojami ịrankiai ir priemonès ${ }^{23}$; 2) smūgiai suduoti i̇ gyvybiškai svarbius organus ${ }^{24}$; 3) naudojamas intensyvus ir ilgalaikis smurtas ${ }^{25}$; 4) yra keli nukentejusieji ${ }^{26}$; 5) smurtas pavartotas nukentejusiajam artimoje aplinkoje $\mathrm{e}^{27}$ ir kt.

Kitas svarbus analizuojamos problemos aspektas - kvalifikuojančių požymių ittaka pripažįstant veiką mažareikšme. BK 140 straipsnio 2, 3 dalyse (BK redakcija, galiojanti nuo $2013 \mathrm{~m}$. liepos 13 d.) numatyti kvalifikuojantys požymiai: veikos padarymas prieš savo artimąji giminaitị, šeimos narị ar mažametị bei kankinimas. Vienu atveju baudžiamosios atsakomybės atsiradimas susietas su vertinamuoju nusikaltimo sudèties požymio - kankinimo - egzistavimu, kurị nustačius pripažinti veiką mažareikšme negalima. Kankinimo požymis daro veiką pavojingą, todèl teismas negali laikyti jos daugiau ar mažiau pavojinga ir jos pagrindu pripažinęs veiką mažareikšme atleisti asmenị nuo baudžiamosios atsakomybès.

Kitokia situacija yra su kitais numatytais kvalifikuojančiais požymiais - artimas giminaitis, šeimos narys ar mažametis. İstatyme ịtvirtinta fizinio skausmo sukèlimo artimam giminaičiui, šeimos nariui ar mažamečiui nusikaltimo sudètis suformuluota taip, kad pavojingumas, priklausomai nuo bylos aplinkybių, gali būti labai skirtingas. Šis didesnị veikos pavojingumo laipsnị parodantis požymis, atsižvelgiant $\mathfrak{i}$ konkrečias bylos aplinkybes, nepašalina galimybès pripažinti veiką mažareikšme, atsižvelgiant $\mathfrak{i}$ nusikaltimą ir kaltininką apibūdinančių požymių visumą ${ }^{28}$. Autorès nuomone, teis-

23 Žr., pvz., Lazdijų rajono apylinkès teismo $2011 \mathrm{~m}$. kovo $21 \mathrm{~d}$. nuosprendis baudžiamojoje byloje (bylos Nr. PK-18-393/2011); Kauno apygardos teismo Baudžiamųjų bylų skyriaus teisèjų kolegijos 2007 m. rugsejo 7 d. nutartis baudžiamojoje byloje (bylos Nr. 1A-471-238/2007).

24 Žr. pvz., Kauno apygardos teismo Baudžiamųjų bylų skyriaus teisejjų kolegijos 2007 m. rugsèjo 7 d. nutartis baudžiamojoje byloje (bylos Nr. 1A-471-238/2007).

25 Ibid.

26 Žr., pvz., Panevėžio apygardos teismo Baudžiamųjų bylų skyriaus teisèjų kolegijos $2009 \mathrm{~m}$. kovo $30 \mathrm{~d}$. nutartis byloje (bylos Nr. 1A-149-134/2009).

27 Kupiškio rajono apylinkès teismo $2012 \mathrm{~m}$. balandžio 6 d. nuosprendis byloje (bylos Nr. 1-54783/2012).

28 Lietuvos Aukščiausiojo Teismo senato 2000 m. gruodžio 21 d. nutarimas Nr. 29 „Dèl teismų praktikos veikas pripažįstant mažareikšmèmis (BK 8 str. 2 d.)“. Teismų praktika. 1997, Nr. 14, p. 413-416. 
mas už fizinio skausmo sukèlimą mažamečiui gali atleisti asmenį nuo baudžiamosios atsakomybès dèl mažareikšmiškumo ir tuomet, kai yra ją kvalifikuojantis požymis (mažametis), jei kiti padaryto nusikaltimo požymiai mažareikšmiai. Svarbu tai, kad veikos pavojingumas nesiektų to laipsnio, kuris būtinas baudžiamajai atsakomybei atsirasti.

Šiame kontekste paminètina kasacinio teismo nutartis, kurioje nurodyta: pagal baudžiamaji istatyma sprendžiant, ar kaltininko veika yra mažareikšmé, esminę reikšmę turi ne nukentèjusiojo veiksmu (net ir neteisètu) pobūdis, ju sukelti padariniai, bet kaltininko veika, šios veikos padarymo büdas, jos padariniai ir, svarbiausia, késinimosi objekto (kuriuo nagrinejamojoje byloje yra mažamečio asmens sveikata) vertybè. Pažymètina ir tai, kad ịstatymu leidejas, BK 140 straipsnio 2 dalyje nustatęs sugriežtinta (sustiprinta) mažamečio sveikatos apsauga nuo mušimo ar kitokio smurto, tuo pačiu įtvirtino ir prezumpciją, jog bet kuriu tyčiniu neteisètu veiksmu, numatytu BK 140 straipsnio 1 dalyje, atlikimas prieš mažametị laikomas kvalifikuotu nusikaltimu. Taigi šioje byloje, kurioje V. Š. kaltinamas padaręs veika, numatyta BK 140 straipsnio 2 dalyje (BK redakcija, galiojusi iki $2013 \mathrm{~m}$. liepos 13 d.), BK 37 straipsnis netaikytinas ${ }^{29}$.

Šioje kasacinejje nutartyje išsakyta gana kategoriška nuostata šiuo klausimu. Nors kitose bylose neatmetė galimybès taikyti ${ }^{30}$. Net ir atsižvelgiant ị nukentejjusio asmens požymius (mažametystę), šio nusikaltimo pavojingumo laipsnis dèl nežymių padarinių nèra toks didelis, nesiekia tokio laipsnio, kuris paneigtų galimybę taikyti atleidimą nuo baudžiamosios atsakomybės dẻl nusikaltimo mažareikšmiškumo. Pažymètina ir tai, kad neretai nuteistuoju tampa mažamečio šeimos narys (vienas iš tèvų), tad tokios griežtos sankcijos (laivès atėmimo bausmès) šalutinis poveikis būna itin neigiamas. Nustatomos poveikio priemonès turi būti proporcingos (adekvačios) teisès pažeidimui, jos turi atitikti siekiamus teisètus ir visuotinai svarbius tikslus. Atsižvelgiant $\mathfrak{i}$ tai fizinio skausmo sukèlimas mažamečiui pagal konkrečias bylos aplinkybes gali būti pripažintas mažareikšme veika.

\section{Išvados}

1. Fizinio skausmo sukèlimo pripažinimas nusikaltimu pagal BK 140 straipsni neturi būti daromas vien formaliai, nevertinant, ar tokios veikos neteisètumas yra kriminalinio pobūdžio ir ar jos pavojingumas yra pakankamas ją laikyti nusikaltimu. Baudžiamoji atsakomybė gali būti taikoma tik tuo atveju, kai asmens elgesio neteisètumas siekia būtiną baudžiamosios atsakomybès taikymui pavojingumo laips-

29 Lietuvos Aukščiausiojo Teismo Baudžiamųjų bylų skyriaus teisejų kolegijos 2006 m. spalio 11 d. nutartis baudžiamojoje byloje (bylos Nr. 2K-558/2006).

30 Lietuvos Aukščiausiojo Teismo Baudžiamųjų bylų skyriaus teisèjų kolegijos $2007 \mathrm{~m}$. sausio 26 d. nutartis baudžiamojoje byloje (bylos Nr. 2K-80/2007); Lietuvos Aukščiausiojo Teismo Baudžiamųjų bylų skyriaus teisèjų kolegijos $2013 \mathrm{~m}$. sausio $8 \mathrm{~d}$. nutartis baudžiamojoje byloje (bylos Nr. 2K-10/2013). 
nị. Sukelto skausmo intensyvumas ir stiprumas, taip pat skausmo keliamas pavojus konkretaus žmogaus sveikatai ar gyvybei yra baudžiamosios atsakomybès taikymo kriterijai.

2. Konstatuoti fizinị skausmą nèra būtinos specialios medicininės žinios. Fizinio skausmo sukèlimo faktą gali nustatyti ir pats teismas remdamasis bylos medžiagos duomenimis, patvirtinančiais buvusị mušimo ar kitokio smurtavimo faktą.

3. Nustatant fizinio skausmo sukèlimą kaip pavojingą veiką, reikia remtis konkretaus nukentejusiojo suvokimu (subjektyviuoju kriterijumi) ir fizinio poveikio gebèjimu paveikti vidutinị žmogų (objektyviuoju kriterijumi), atsižvelgiant ị konkretaus nukentejjusiojo fizinius duomenis bei kitas aplinkybes.

4. Nežymus sveikatos sutrikdymas ar fizinio skausmo sukèlimas pagal pavojingumą gali būti labai skirtingo pobūdžio, todèl galimi atvejai, kai asmuo bus atleidžiamas nuo baudžiamosios atsakomybès dèl nusikaltimo mažareikšmiškumo. Mažareikšmiu nusikaltimu pripažịstama veika, kuri tik formaliai atitinka nusikaltimo sudèties požymius, bet iš esmès nedaro žalos įstatymo saugomoms vertybèms ar nesukelia pavojaus tokiai žalai atsirasti, arba kuri nesiekia tokio pavojingumo laipsnio, dèl kurio būtų tikslinga kaltininką už padarytą nusikaltimą traukti baudžiamojon atsakomybèn.

5. BK 140 straipsnio 3 dalyje įtvirtinta fizinio skausmo sukèlimo mažamečiui nusikaltimo sudètis suformuluota taip, kad pavojingumas, priklausomai nuo bylos aplinkybių, gali būti labai skirtingas. Net ir atsižvelgiant i̇ nukentejjusio asmens požymius (mažametystę), šio nusikaltimo pavojingumo laipsnis dẻl nežymių padarinių nèra toks didelis, nesiekia tokio laipsnio, kuris paneigtų galimybę taikyti atleidimą nuo baudžiamosios atsakomybès dèl nusikaltimo mažareikšmiškumo. Fizinio skausmo sukèlimas mažamečiui pagal konkrečias bylos aplinkybes gali būti pripažintas mažareikšme veika.

\section{Literatūra}

Abramavičius, A., et al. Baudžiamoji teisè. Specialioji dalis. 1 knyga. Vilnius: Eugrimas, 2001.

Abramavičius, A., et al. Lietuvos Respublikos baudžiamojo kodekso komentaras. Specialioji dalis (99-212 straipsniai). Vilnius: valstybės įmonė Registrų centras, 2009.

Aliukonienė, R. Nusikaltimų žmogaus sveikatai samprata. Nepriklausomos Lietuvos teise: praeitis, dabartis ir atei- tis. Vilnius: Vilniaus universitetas, 2012.

Baudžiamojo kodekso patvirtinimo ir ịsigaliojimo istatymas. Valstybès žinios. 2000, Nr. 89-2741.

Grinevičiūtè, K. Fizinès bausmès vaikams: baudžiamasis teisinis vertinimas. Socialiniu mokslų studijos. 2011, 3(2).

Kauno apygardos teismo Baudžiamųjų bylų skyriaus teisejjo $2012 \mathrm{~m}$. gruodžio 
21 d. nutartis byloje (bylos Nr. 1S2084-317/2012).

Kauno apygardos teismo Baudžiamųjų bylų skyriaus teisèjų kolegijos 2012 $\mathrm{m}$. birželio $11 \mathrm{~d}$. nutartis byloje (bylos Nr. 1A-462-508/2012).

Kauno apygardos teismo Baudžiamųjų bylų skyriaus teisejjų kolegijos 2007 m. rugsejo $7 \mathrm{~d}$. nutartis baudžiamojoje byloje (bylos Nr. 1A-471-238/2007).

Klaipèdos apygardos teismo Baudžiamųjų bylų skyriaus teisèjų kolegijos 2010 m. lapkričio $9 \mathrm{~d}$. nutartis byloje (bylos Nr. 1S-753-107/2010).

Klaipèdos apygardos teismo Baudžiamųjų bylų skyriaus teisèjų kolegijos 2007 m. lapkričio 15 d. nutartis baudžiamojoje byloje (bylos Nr. 1S-108361/2007).

Kupiškio rajono apylinkès teismo 2012 m. balandžio $6 \mathrm{~d}$. nuosprendis byloje (bylos Nr. 1-54-783/2012).

Lazdijų rajono apylinkès teismo $2011 \mathrm{~m}$. kovo $21 \mathrm{~d}$. nuosprendis baudžiamojoje byloje (bylos Nr. PK-18-393/2011).

Lietuvos Aukščiausiojo Teismo Baudžiamųjų bylų skyriaus teisèjų kolegijos 2008 m. kovo 4 d. nutartis baudžiamojoje byloje (bylos Nr. 2K-68/2008).

Lietuvos Aukščiausiojo Teismo senato $2000 \mathrm{~m}$. gruodžio $21 \mathrm{~d}$. nutarimas Nr. 29 „Dèl teismų praktikos veikas pripažistant mažareikšmėmis (BK 8 str. 2 d.)“. Teismu praktika. 1997, 14.

Lietuvos Aukščiausiojo Teismo Baudžiamųjų bylų skyriaus teisèjų kolegijos $2006 \mathrm{~m}$. spalio $11 \mathrm{~d}$. nutartis baudžiamojoje byloje (bylos Nr. 2K558/2006).

Lietuvos Aukščiausiojo Teismo Baudžiamųjų bylų skyriaus teisejų kolegijos 2007 m. sausio 26 d. nutartis baudžiamojoje byloje (bylos Nr. 2K-80/2007).
Lietuvos Aukščiausiojo Teismo Baudžiamųjų bylų skyriaus teisejjų kolegijos 2013 m. sausio 8 d. nutartis baudžiamojoje byloje (bylos Nr. 2K-10/2013).

Nemerofsky, J. What is a "Triffle" Anyway? Gonzaga Law Journal. 20012002, 37.

Panevėžio apygardos teismo Baudžiamųjų bylų skyriaus teisèjų kolegijos $2012 \mathrm{~m}$. balandžio $30 \mathrm{~d}$. nuosprendis byloje (bylos Nr. 1A-295-350/2012).

Panevėžio apygardos teismo Baudžiamųjų bylų skyriaus teisejjų kolegijos 2012 m. gegužès 18 d. nuosprendis baudžiamojoje byloje (bylos Nr. 1A19-511/2012).

Panevėžio apygardos teismo Baudžiamųjų bylų skyriaus teisèjų kolegijos 2009 m. kovo $30 \mathrm{~d}$. nutartis byloje (bylos Nr. 1A-149-134/2009).

Sveikatos sutrikdymo masto nustatymo taisyklès. Valstybès žinios. 2003, Nr. 522357.

Sharapov, R. D. Fizicheskoe nasilie v ugolovnom prave [Physical abuse in criminal law]. Sankt-Peterburg: Juridicheskij centr Press, 2001.

Stewart, H. Parents, Children, and the Law of Assault. The Dalhousie Law Journal. 2009, 32.

Šiaulių apygardos teismo Baudžiamųjų bylų skyriaus teisejjų kolegijos $2010 \mathrm{~m}$. vasario $18 \mathrm{~d}$. nuosprendis byloje (bylos Nr. 1A-19-282/2010).

Šilutès rajono apylinkès teismo 2006 $\mathrm{m}$. gruodžio $12 \mathrm{~d}$. nuosprendis baudžiamojoje byloje (bylos Nr. 1-449351/2006).

Vitkutè-Zvezdinienè, I. Nusikaltimo mažareikšmiškumo atribojimo nuo baudžiamojo nusižengimo problemos. Jurisprudencija. 2007, 8(98). 
Anotacija. Straipsnyje analizuojama nusikaltimo, numatyto Lietuvos Respublikos baudžiamojo kodekso 140 straipsnyje, sudeties taikymo probleminiai aspektai. Daugiausia demesio skiriama fizinio skausmo nustatymo problemai. Straipsnyje autorẻ aptaria fizinio skausmo ir nežymaus sveikatos sutrikdymo pripažinimo mažareikšmèmis veikomis problematiką. Teorine analizè grindžiama teismų praktika.

Reikšminiai žodžiai: sveikatos sutrikdymas, fizinis skausmas, fizinis smurtas, mažareikšmé veika.

\title{
PROBLEMATIC ASPECTS OF THE STATEMENT OF CAUSING OF PHYSICAL PAIN AND RECOGNITION OF MINORITY OF CRIME PROVIDED IN ARTICLE 140 OF THE CC
}

\section{Kristina Grinevičiūtè}

\author{
Mykolas Romeris University, Lithuania
}

Summary. Article 140 of the Criminal Code of the Republic of Lithuania establishes liability for beating or other violent actions, which cause to a person physical pain or a negligible bodily harm or a short-term illness. The article does not provide a boundary when physical abuse shall not be considered a crime, as allegedly there shall be a punishment only for causing of physical pain. Article 140 of the CC criminalizes one of the lightest consequences of physical abuse - causing of physical pain. Does this mean that any abuse or using of physical force towards another person's body shall always carry criminal liability? The answer to this question is directly related to the range of problems of physical pain definition in criminal law, so the article includes the analysis of problem related to the assessment of causing of physical pain in criminal law. The objective of the article is to assess the problems of physical pain feature definition and distinguish criteria for its proof in criminal cases applying system-based, logical, court practice assessment and other research methods. Simultaneously, the author of the article will try to answer whether physical pain and negligible bodily harm could be recognized as a minor crime.

It should be mentioned that physical abuse does not always cause physical pain, and not every caused physical pain is dangerous, illegal and harmful. While applying criminal liability for causing of physical pain, one has to define the boundaries of criminality of such actions reasonably. Adjudging of person's actions, a crime shall not be made just formally without assessment of the fact whether the illegality of such actions has criminal nature, and whether their hazard is sufficient for considering them a crime. A formal statement that physical pain is caused is not enough. Criminal liability can be applied only in the case when the illegality of person's behavior reaches criminal liability application hazard level. The intensity and degree of caused physical 
pain, as well as harm of caused pain to life and health of a certain person, shall be criteria for the application of criminal liability. The article also includes the conclusion that special medical knowledge is not required for the statement of physical pain. The fact of causing of physical pain can be stated by the court basing on the case material data, confirming the fact of previous beating or other violent actions. While stating that causing of physical pain is a harmful act, one shall base on the perception of a certain injured person (subjective criteria) and physical ability to make harm to a person (objective criteria), considering physical ability of a certain injured person.

Harm of short-term illness or causing of physical pain can be of completely different nature, so there are cases when a person will be released from criminal liability due to the minority of crime. Components of crime related to causing of physical pain to a young child are established in Part 3 of Article 140 of the CC, so that the harm, depending of case circumstances, can be completely different. Even considering physical ability of an injured person (minority), the crime harmfulness degree is low due to insignificant consequences, and it does not reach the degree which closes out application of release from criminal liability due to the minority of crime. Causing of physical pain to a young child can be recognized as a minor crime according to certain case circumstances.

Keywords: health impairment, physical pain, physical abuse, minor crime.

Kristina Grinevičiūtė, Mykolo Romerio universiteto Teisès fakulteto Baudžiamosios teisès ir proceso instituto lektorè. Mokslinių tyrimų kryptys: nusikaltimai ir baudžiamieji nusižengimai vaikui ir šeimai.

Kristina Grinevičiūtė, Mykolas Romeris University, Faculty of Law, Institute of Criminal Law and Procedure, lecturer. Research interests: crimes and misdemeanors against child and family. 